\title{
MENGURAI POLEMIK HUKUM ZIARAH KUBUR BAGI PEREMPUAN
}

\author{
ABDUL WAFI MUHAIMIN \\ Ma'had Aly al-Musthafawiyah Megamendung Bogor \\ Email: wafimuhaimin@gmail.com
}

\section{Abstrak}

Grave pilgrimage in Indonesia becomes its own power. The crowded burial places that were rescued, such as the burial of saints, religious leaders and national figures, became an interesting thing to study, especially as women increasingly dominated the sacred tombs. Deviations made by some pilgrims, both in the form of procedures, culturing and the mixing of men and women resulting of appearance of accusation of polytheism and forbidden conduct from some groups who did not like the grave pilgrimage tradition. Moreover, there many hadiths that indicate that a curse for women who do the grave pilgrimage. The many hadiths that curse women go to the grave (pilgrimage) need to be studied and examined carefully so as not to make mistake in giving a fatwa. The hadith about the grave pilgrimage for a woman is not one only hadith. There are several different hadith with different term and even look contradictory to each other. The difference in the term of thus hadiths will provide a logical consequence of the differences of fatwa around the grave pilgrimage for women.

\section{Keywords}

Hadith, Polemic, Grave Pilgrimage, Women.

\section{Pendahuluan}

Pro kontra seputar hukum ziarah kubur kerapkali mencuat dan melahirkan permusuhan. Hal ini disebabkan karena para pelaku ziarah kubur sering dituduh menyembah kuburan dan divonis syirik (sesat), sementara para pelakunya tidak terima dituduh menyembah kuburan. Antara satu 
golongan dengan golongan lainnya saling merasa benar dan masing-masing mencari pembenaran dari teks-teks agama (Alquran dan hadis). Bahkan bukan hanya persoalan tata cara pelaksanaannya saja yang dipersoalkan, akan tetapi para pelakunya pun menjadi sasaran vonis laknat, khususnya bagi penziarah perempuan. Golongan yang menolak ziarah kubur bagi perempuan, menjadikan hadis-hadis dengan redaksi laknat sebagai pembenaran atas keyakinan mereka. Di sisi lain, kelompok yang suka melakukan ziarah kubur, sebagai bentuk wasilah dalam melangitkan hajat-hajat mereka melalui para wali Allah yang sudah wafat, tidak mau kalah dan tinggal diam. Mereka juga mempunyai pembenaran dengan berpegang pada dalil-dalil anjuran ziarah kubur.

Persoalan ini harus didudukkan dengan semestinya, bukan mencari pembenaran untuk menguatkan kelompok atau mazhab masing-masing, melainkan mencari kebenaran dengan mengesampingkan arogansi dan fanatisme golongan ('ashabiyah). Untuk mencari kebenaran, tentu diperlukan ketelitian dan kecermatan di dalam mengurai dalil-dalil seputar ziarah kubur, khususnya bagi perempuan. Karena tak jarang, secara zhahir teks-teks hadis terkesan saling bertentangan satu sama lainnya, dan baik yang suka melakukan ziarah maupun yang anti ziarah akan menemukan pembenaran atas keyakinannya masing-masing. Maka dibutuhkan kajian yang komprehensif di dalam mendudukkan masalah ini dengan sebisa mungkin menggunakan pendekatan komparatifkompromistik (al-muqaranah wa al-jam'u).

Oleh karena itu, tulisan ini akan mencoba menjawab pertanyaan-pertanyaan sebagai berikut: (1) Bagaimana redaksi hadis tentang laknat ziarah kubur bagi perempuan? (2) Bagaimana status hadis-hadis yang redaksinya melaknat ziarah kubur bagi perempuan? (3) Bagaimana mempertemukan hadis- 
hadis laknat dengan hadis kebolehan ziarah kubur? (4) Bagaimana hukum ziarah kubur bagi perempuan menurut para ulama?

\section{Redaksi Hadis Laknat Ziarah Kubur Bagi Perempun}

Ada beberapa redaksi hadis seputar laknat ziarah kubur bagi seorang perempuan, diantaranya:

a. Dari Abu Hurairah Radhiallahu 'anhu:

$$
\text { إن رسول الله صلى الله عليه وسلم لعن زائرات القبور }
$$

Artinya:

"Sesungguhnya Rasulullah melaknat para wanita yang menziarahi kuburan."

Hadis ini diriwayatkan oleh al-Tirmidzi dan dishahihkan oleh Ibnu Hibban, ${ }^{1}$ dan juga diriwayatkan oleh Ibnu Majah dalam Sunan Ibnu Majah. Menurut Imam Tirmidzi, status hadis ini adalah hasan. ${ }^{2}$ Bahkan dalam riwayat yang lain beliau menganggap hadis ini adalah hadis hasan-shahih karena banyaknya jalur (yang meriwayatkan).

b. Dari Ibnu Abbas Radhiallahu 'anhu:

لعن رسول الله صلى الله عليه وسلم زائرات القبور والمتخذين عليها المساجد و السرج

Artinya:

"Rasulullah melaknat para wanita yang menziarahi kuburan dan menjadikannya sebagai masjid serta (menyalakan) lentera (lampu)."

1Ibnu Hajar al-'Asqalani, Bulughul Maram, (Indonesia: Dar Ihya' alKutub al-Arabiyah), 122.

2 Hasan bin Ali al-Qanuji al-Bukhari al-Hindi, Fath al-'Allam li Syarh Bulugh al-Maram, Juz 1, (Beirut: Dar al-Kotob al-Ilmiyah, 1997), 490. 
Hadis ini diriwayatkan oleh an-Nasai dalam bab alJanaiz (hadis no 2039), Abu Daud dalam bab al-Janaiz (hadis no. 3236), at-Tirmidzi dalam bab Shalat (hadis no. 320), dan Ibnu Majah dalam bab al-Janaiz (hadis no. 1571). Sanad hadis ini keseluruhannya dari Ibnu Abbas. Imam Ahmad dalam Musnadnya meriwayatkan dari Yahya, dari Syu'bah, dari Muhammad bin Jihadah, dari Abu Shaleh dari Ibnu Abbas. Ada juga dari jalur riwayat Abu Daud dari Muhammad bin Katsir, dari Syu'bah, dari Muhammad bin Jihadah, dari Abu Shaleh dari Ibnu Abbas. ${ }^{3}$ Kecuali Ibnu Hibban meriwayatkan dengan sanad yang lain dari jalur Abu Hurairah, yaitu: diriwayatkan dari Muhammad bin Abdullah bin Junaid, dari Qutaibah bin Said, dari Abu 'Awanah, dari Umar bin Abi Salamah, dari bapaknya, dari Abu Hurairah. Adapun status hadis ini adalah termasuk hadis hasan.

c. Dari Abu Hurairah Radhiallahu 'anhu:

Artinya:

$$
\text { أن رسول الله لعن زوارات القبور }
$$

"Sesungguhnya Rasulullah melaknat para wanita yang sering menziarahi kuburan."

Hadis ini diriwayatkan oleh Ibnu Majah no. 1641, 1642, 1643, Tirmidzi no. 1076, dan Ahmad no. 8904. Dari jalur Imam Tirmidzi, hadis ini diriwayatkan dari Qutaibah, dari Abu 'Awanah, dari Umar bin Abi Salamah, dari bapaknya, dari Abu Hurairah. Setelah meriwayatkan hadis ini, imam Tirmidzi

${ }^{3} \mathrm{Abu}$ Daud Sulaiman bin al-Asy'ats al-Sajastani, Sunan Abi Daud, (Beirut: Dar al-Fikr, 2011), 
dalam kitab Sunannya mengatakan bahwa status hadis ini adalah hasan-shahih. ${ }^{4}$

Ada juga yang menggunakan redaksi:

$$
\text { أن رسول الله قال: لعن الله زوارات القبور5 }
$$

Artinya:

"Allah melaknat para wanita yang sering menziarahi kuburan."

Menurut imam al-Qurthubi, laknat dalam hadis ini ditujukan kepada para wanita yang sering mendatangi kuburan sebagaimana lafazh hadisnya menggunakan sighat mubalaghah. ${ }^{6}$

Imam Ahmad meriwayatkan dengan dua redaksi:

- Redaksi dari Abu Hurairah menggunakan zuwwaraat, demikian juga riwayat dari Hassan

- Redaksi dari Ibnu Abbas dengan menggunakan lafazh zaairaat.

Untuk lebih jelasnya, berikut penulis cantumkan beberapa perbedaan redaksi dan juga kitab-kitab yang meriwayatkan hadis seputar laknat ziarah kubur bagi perempuan dengan menggunakan bantuan digital $^{7}$ untuk melacaknya:

1. Jalur hadis yang menggunakan redaksi زعن رسول الله زوار ات القبور

${ }^{4}$ Muhammad 'Isa bin Saurah al-Tirmidzi, Sunan al-Tirmidzi, dikomentari oleh alBani, (Riyadl: Maktabah al-Ma'arif li an-nasyr wa altawzi'), 250.

5 Mahmud bin Ahmad al-Aini, Umdah al-Qari Syarah Shahih alBukhari, Juz 8 (Beirut: Dar al-Kutub al-Ilmiyah, 2001), 100.

6 Ibnu Hajar al-'Asqalani, Fathul-Bari Syarah Shahih al-Bukhari, Juz 3, (al-Azhar: Dar al-Bayan al-'Arabi, 2007), 174.

7 http://library.islamweb.net/hadith/hadithsearch.php 


\begin{tabular}{|c|c|c|c|c|c|c|c|}
\hline p & طرف الحديث & الصحابي & اسم الكتاب & أقثق & 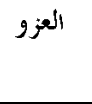 & المصنف & سلوفة \\
\hline 1 & لعن رسول الله زوارات القبور & عبد الله بن & سنن ابن ماجه & 1564 & 1575 & ابن ماجة القزو يني & 275 \\
\hline 2 & لعن رسول الله زوارات القبور & ثابت & سنن ابن ماجه & 1563 & 1574 & ابن ماجة القزويني & 275 \\
\hline 3 & لعن رسول الله زوارات القبور & عبد الرحمن بن & سنن ابن ماجه & 1565 & 1576 & ابن ماجة القزويني & 275 \\
\hline 4 & لعن رسول الله زوارات القبور & ثابت & المستدرك & 1317 & $\begin{array}{l}1: \\
374\end{array}$ & النحاكم & 405 \\
\hline 5 & لعن رسول الله زوارات القبور & ثابت & للبيهتي & 6660 & $\begin{array}{l}4: \\
78\end{array}$ & البيهقي & 458 \\
\hline 6 & والمت رسول الله زوارات القبور & عبد الله بن & مسند أبي داود & 2847 & 2856 & 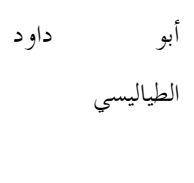 & 204 \\
\hline 7 & لعن رسول الله زوارات القبور & ثابت & مسند ابن أبي شيبة & 618 & 617 & ابن ابي شيبة & 235 \\
\hline 8 & لعن رسول الله زوارات القبور & ثابت & قعجم الصحابة لابن & 743 & 410 & ابن قانع البغدادي & 351 \\
\hline 9 & لعن رسول الله زوارات القبور & عبد الله بن & التمهيد لابن عبد البر & 550 & $\begin{array}{l}3: \\
232\end{array}$ & ابن & 463 \\
\hline 10 & لعن رسول الله زوارات القبور & صبد الرحمن بن & التمهيد لابن عبد البر & 552 & $\begin{array}{l}3: \\
234\end{array}$ & ابن & 463 \\
\hline 11 & لعن رسول الله زوارات القبور & عبد الله بن & والجامع ب في العلل & 524 & 1946 & أحمد بن حنبل & 241 \\
\hline 12 & لعن رسول الله زوارات القبور & ثابت & 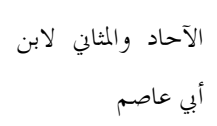 & 1838 & 2071 & 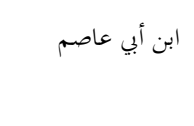 & 287 \\
\hline 13 & لعن رسول الله زوارات القبور & ثابت & عاريخ دمشق لابن & 34747 & --- & ابن & 571 \\
\hline 14 & لعن رسول الله زوارات القبور & 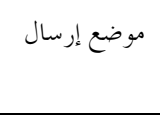 & عساكر & 34746 & --- & ابن الدمشقي & 571 \\
\hline
\end{tabular}




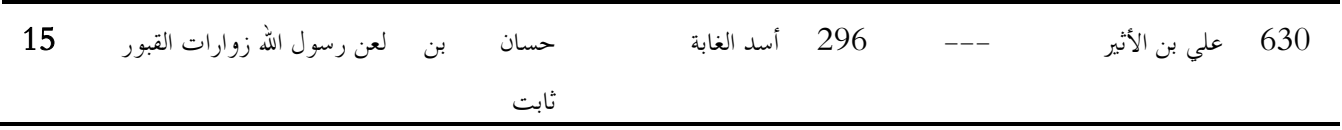

2. Jalur hadis yang menggunakan redaksi: لعن رسول الله زائرات القبور والمتخذين عليها المساجد والسرج

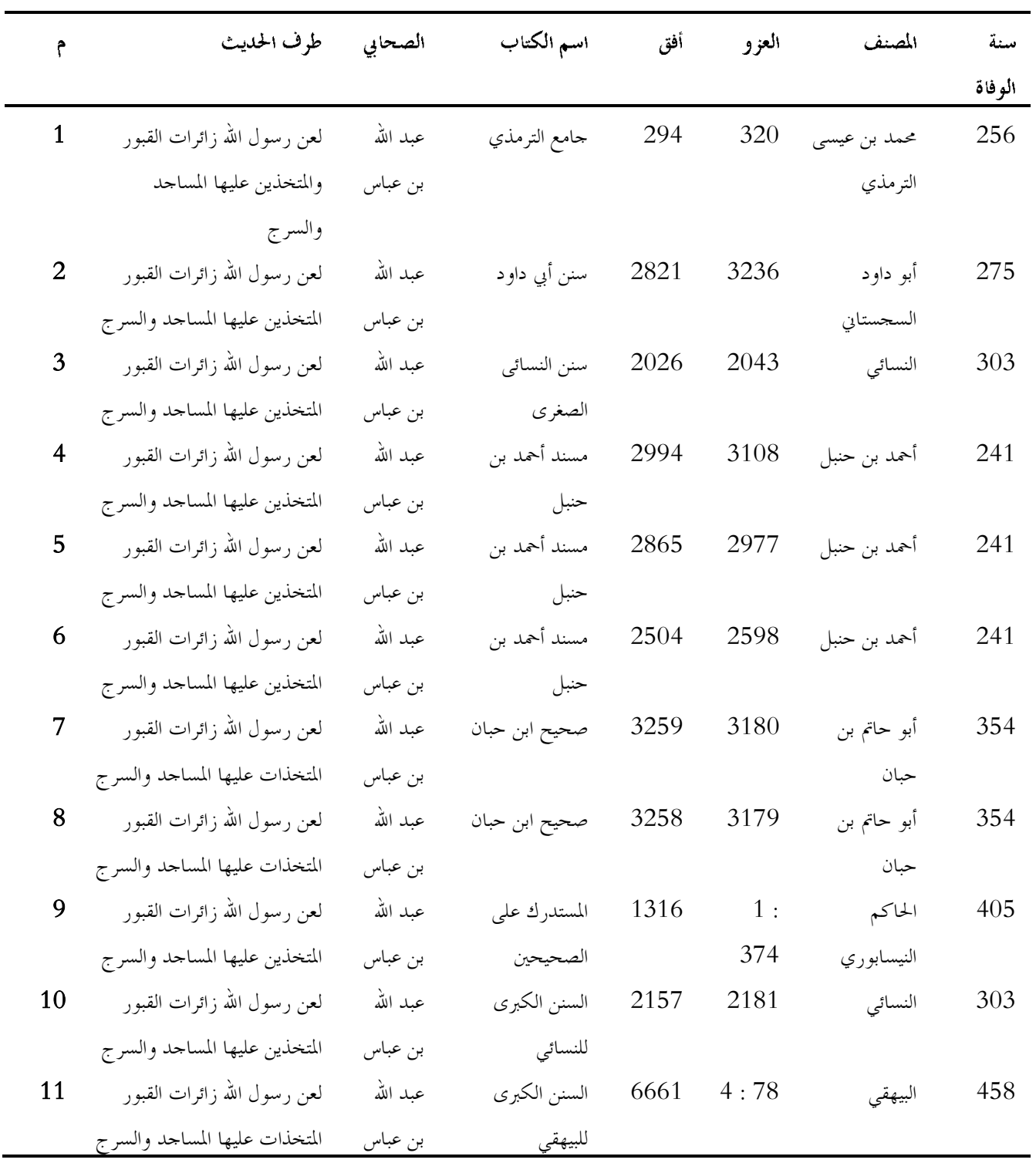




\begin{tabular}{|c|c|}
\hline لعن رسول الله زائرات القبور & عبد الله \\
\hline المتخذات عليها المساجد وال & بن عباس \\
\hline
\end{tabular}

لعن رسول الله زائرات القبور

$$
\text { للحربي }
$$

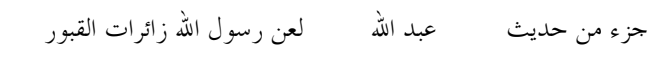

$$
\text { بن عبد الله لعن رسول الله زائرات القبور }
$$$$
\text { شرح السنة }
$$$$
508
$$$$
510
$$$$
\text { الحسين بن }
$$

$$
\text { الأصبهاني }
$$

\section{Analisis Sanad Hadis Tentang Laknat Ziarah Kubur}

1. Imam Ahmad, Tirmidzi dan Ibnu Majah meriwayatkan hadis larangan ziarah kubur bagi perempuan dengan tiga jalur:

- Dari jalur Abu salamah, dari Abu Hurairah

- Dari jalur Abu Shaleh, dari Ibnu Abbas

- Dari jalur Abdurrahman bin Hassan, dari bapaknya

2. Riwayat Riwayat Abu Daud

3. Riwayat Nasai 
4. Riwayat Abu Daud al-Tayalisi, dari Ibnu Abbas

5. Ibnu Hibban di dalam kitab shahihnya, dari $\mathrm{Abu}$ Hurairah dan Ibnu Abbas

6. Al-Hakim, dari Hassan bin Tsabit ${ }^{8}$

Dari banyaknya jalur, secara garis besar bisa difokuskan menjadi dua:

\section{a. Jalur Ibnu Abbas}

Pada jalur Ibnu Abbas, perawi Abu Shaleh masih diperdebatkan soal namanya yang sebenarnya dikalangan ulama. Perbedaan pendapat seputar nama sebenarnya dari Abu Shaleh mengerucut menjadi dua pendapat:

1) Mizan al-Bashri Abu Shaleh. Pendapat ini dipegang oleh Ibnu Hibban dalam kitab shahihnya.

2) Badzam, budak ummu Hani'. Ada juga yang menyebut Badzan (nun). Pendapat ini dipegang oleh Imam al-Hakim, Abdul Haq al-Isybili, Ibnu alQatthan, Ibnu 'Asakir, al-Mundzir, Ibnu Dahiyah, dan lain sebagainya. ${ }^{9}$

Dengan dua kemungkinan nama $\mathrm{Abu}$ Shaleh di atas, hadis la'ana zaairaat al-qubur tetap dianggap hadis shahih, baik yang dimaksud Abu Shaleh adalah Mizan maupun Badzam. Ibnu Hatim mengatakan dalam al-Jarah wa al-Ta'dil: "Aku tidak melihat satupun dari sahabat-sahabatku yang meninggalkan Abu shaleh, budak Ummu Hani', dan tak satupun aku mendengar dari orang-orang mengatakan yang bukan-bukan tentang dirinya." Bahkan Sa'id, Zaidah, dan Abdullah bin

8 Abdurrahman bin Hassan bin Mundzir bin Amr bin Haram alAnshari. Ibnu Ma'in menyebutkan bahwa ia termasuk tabiin dan ahli hadisnya penduduk Madinah. Ibnu Sa'ad mengatakan ia termasuk penyair yang sedikit meriwayatkan hadis. Namun Ibnu Hibban memasukkan ke dalam kitab as-Tsiqaat-nya. lihat at-Tahdzib, 4/32.

${ }^{9}$ Ibnu Hajar al-Asqalani, Tahdzib Al-Tahdzib fi Rijal al-Hadits, Juz 1 , (Beirut: Dar al-Kutub al-Ilmiyah, 2004), 391. 
Utsman tidak meninggalkan (riwayat darinya). Yahya bin Ma'in berkata: "Tidak ada masalah dengan Abu Shaleh, budak Ummu Hani', karena ketika al-Kalbi meriwayatkan darinya, maka itu menandakan tidak ada masalah..."

Inilah pendapat yang paling adil kaitannya dengan $\mathrm{Abu}$ Shaleh, budak Ummu Hani', sebagaimana dikatakan oleh syekh Ahmad Syakir dalam Hasyiahnya pada kitab Musnad Imam Ahmad: "Yang benar (faktanya), Abu Shaleh, budak Ummu Hani' adalah tsiqah (terpercaya). Tidak ada hujah bagi yang melemahkannya (mendhaifkannya)..." Secara sanad, syekh Ahmad Syakir mengatakan bahwa hadis la'ana zaairaat alqubur sanadnya shahih.

Oleh karena itu, Imam Tirmidzi, al-Baghawi, Ibnu Hajar dan Ahmad Syakir (dalam Syarah Tirmidzi) menganggap status hadis yang diriwayatkan oleh Qutaibah dari Abdul Warits bin Said, dari Muhammad bin Jihadah, dari Abi Shaleh, dari Ibnu Abbas adalah hasan. Walaupun menurut al-Bani, dalam Silsilah adh-Dha'ifah no 225, hadis ini dha'if karena dalam sanadnya ada Abu Shaleh (Badzam).

\section{b. Jalur Abu Hurairah}

Ibnu Hibban berkata: "Meriwayatkan kepada kami Muhammad bin Abdullah bin Junaid, dari Qutaibah bin Said, dari Abu 'Awanah, dari Umar bin Abi Salamah, dari bapaknya, dari Abu Hurairah."

Umar di sini adalah Umar bin Salamah bin Abdurrahman bin 'Auf saudara Muslim. Abu Hatim berkata: "Menurutku, dia (Umar) adalah orang yang shaleh dan jujur, yang menulis hadisnya dan tidak ada bukti bahwa ia menyalahi sebagiannya. Ad-Dzahabi berkata: "Imam Tirmidzi menshahihkan hadis la'ana Rasulullah zuwwaraat al-qubur yang diriwayatkan olehnya (Umar)." Namun Abdul Haq mengkritiknya dengan mengatakan bahwa Umar adalah dha'if. Ibnu Ma'in mengatakan 
dalam riwayat Ahmad bin Abi Khatsimah bahwa tidak ada masalah dengan Umar. Dan Ibnu Hibban memasukkan dalam kategori perawi-perawi yang terpercaya (tsiqaat). Ibnu Hajar dalam al-Tahdzib-nya mengatakan bahwa Umar adalah orang yang sangat jujur namun keliru. Dengan ungkapan Ibnu Hajar ini, kita tahu bahwa Umar walaupun (mungkin) keliru, namun kaitannya dengan hadis ini, karena diriwatkan dari banyak jalur maka Umar dalam meriwayatkan hadis ini tidak keliru. Sehingga bisa disimpulkan bahwa hadis tentang laknat ziarah kubur bagi perempuan adalah shahih. ${ }^{10}$

\section{Hadis-Hadis Kebolehan Ziarah Kubur}

Di samping hadis-hadis yang melaknat perempuan melakukan ziarah kubur, terdapat banyak hadis yang redaksinya membolehkan ziarah kubur secara umum. Di antara hadis-hadis yang memboleh ziarah kubur adalah sebagai berikut:

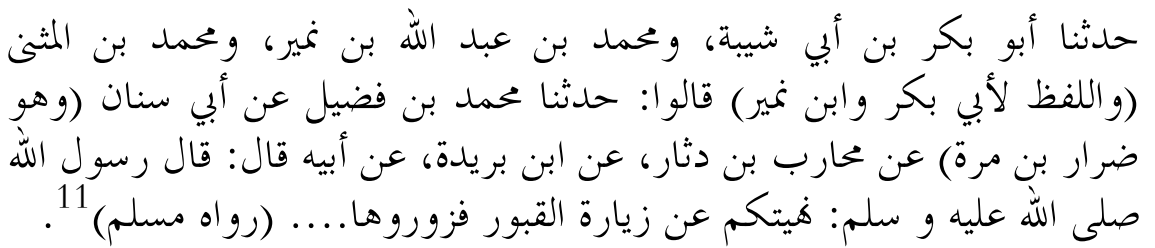

Artinya:

"Telah menceritakan kepada kami Abu Bakar bin Abi Syaibah dan Muhammad bin Abdullah bin Numair dan Muhammad bin al-Mutsanna (lafadznya dari Abu Bakar dan Ibnu Numair), mereka berkata: meriwayatkan kepada kami Muhammad bin Fudhail dari Abu Sinan Cyaitu Dhirar bin

10 Bakar bin Abdullah Abu Zaid, Juz'un fi Ziarah al-Qubur, www.du3at.com.

${ }^{11}$ Abu Husein Muslim bin al-Hajjaj, Shahih Muslim, Juz 1, (Beirut: Dar al-Fikr, 2011), 429-430. 
Murrah) dari Muharib bin Ditsar, dari Ibnu Buraidah, dari bapaknya, ia berkata: Rasulullah bersabda: "Aku melarangmu dari ziarah kubur, maka berziarahlah kamu sekalian ke kuburan." (HR. Muslim).

Abu Daud dan an-Nasai menambahkan dari hadis Anas redaksi فإنها تذكر الآخرة (karena zarah kubur bisa mengingatkan akhirat). Sedangkan Hakim menambah dari hadis Anas redaksi (dan melembutkan hati dan meneteskan air mata, dan janganlah kalian berkata dengan perkataan yang keji), dan riwayat lain dari Hakim dari hadis Ibnu Mas'ud menambahkan redaksi فإِذا تزهد في الدنيا (karena ziarah kubur menyebabkan tidak suka dunia). Adapun redaksi dari imam Muslim dari hadis Abu Hurairah dengan status marfu', yaitu زوروا القبور فإذا تذكر الموت (Datangilah kuburan karena kuburan mengingatkan kematian). ${ }^{12}$

Ada juga hadis riwayat Aisyah yang menjelaskan tentang bolehnya melakukan ziarah kubur:

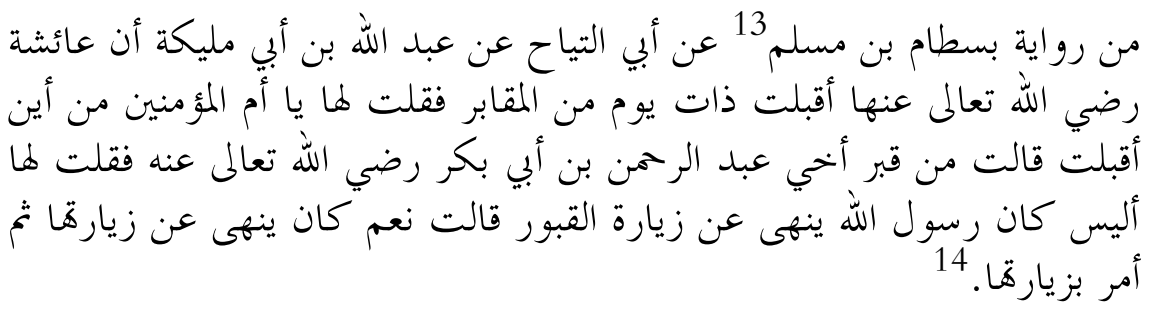

Artinya:

12 Fath al-Bari, 3/173

13 Bistham bin Muslim bin Numair al-'Audzi al-Bashri. Imam Ahmad dan Abu Hatim mengatakan tidak ada masalah, hadisnya sesuai. Abu Daud, Ibnu Hibban, Ibnu Ma'in dan Abu Zur'ah menganggap tsiqah. Demikian juga dengan Nasai menganggap tidak ada masalah. Lihat: Ibnu Hajar al-'Asqalani, Tahdzib al-Tahdzib fi Rijal al-Hadits, juz 5, (Beirut: Dar al-kotob al-Ilmiyah, 2004), 332-334.

${ }^{14}$ Al-Hakim: 1/376, al-Baihaqi: 4/78 (al-Maktabah as-Syamilah).

TAHDIS Volume 10 Nomor 2 Tahun 2019 
"Dari riwayat Bistham bin Muslim dari Abu al-Tayyah dari Abdullah bin Abu Malikah bahwa sesungguhnya Ra. suatu hari datang dari kuburan, maka aku bertanya kepadanya: "Wahai Ummul -Mu'minin, anda datang dari mana?" Beliau menjawab: "Dari kuburan saudaraku, Abdurrahman bin Abu Bakar Ra. Lalu aku bertanya lagi: "Bukankah Rasulullah telah melarang untuk mendatangi kuburan?" Beliau menjawab: "Benar, beliau memang dulu melarangnya, kemudian beliau memerintahkan untuk mendatangi kuburan." (HR. Hakim dan Baihaqi). ${ }^{15}$

Serta hadis berikut ini:

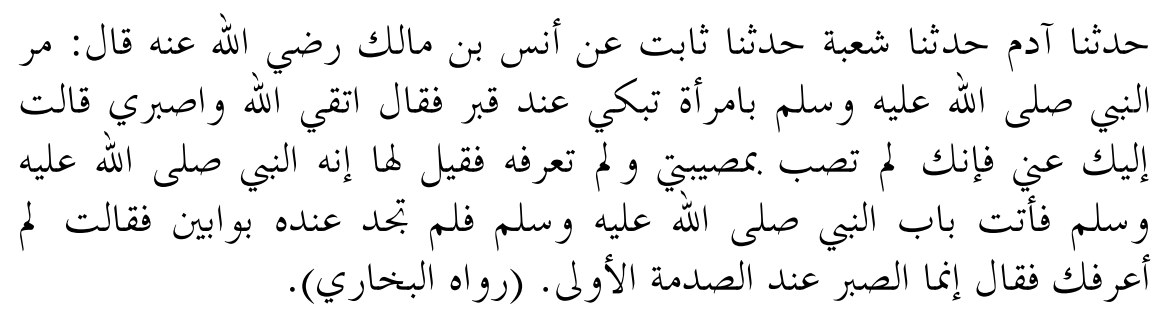

Artinya:

"Meriwayatkan kepada kami Adam, menceritakan kepada kami Syu'bah, menceritakan kepada kami Tsabit, dari Anas bin Malik Ra., ia berkata: Rasulullah lewat bertemu dengan seorang perempuan sedang menangis di samping kuburan. Maka beliau berkata: "Bertakwalah kepada Allah dan bersabarlah!" Perempuan tersebut menjawab: "Menyingkirlah dariku karena engkau tidak tertimpa musibah sepertiku -perempuan tersebut tidak mengetahui bahwa itu adalah nabi- Dikatakan kepadanya bahwa sesungguhnya dia itu Nabi, maka perempuan tersebut mendatangi pintu (rumah) nabi. Dia tidak mendapati

15 Dalam Kaidah Ushul Fiqih ada ungkapan: "al-Amru ba'da an-Nahyi yufidu al-Ibahah" perintah setelah larangan menunjukkan kebolehan. 
penjaga di rumah beliau. Dia berkata: "Aku tidak mengetahui bahwa itu engkau," Maka Nabi berkata: "Kesabaran itu hanyalah di awal musibah." (HR. Bukhari no. 1283 dan Muslim no. 2179, lafadz hadis ini milik Bukhari). ${ }^{16}$

Dan juga dengan hadis ini:

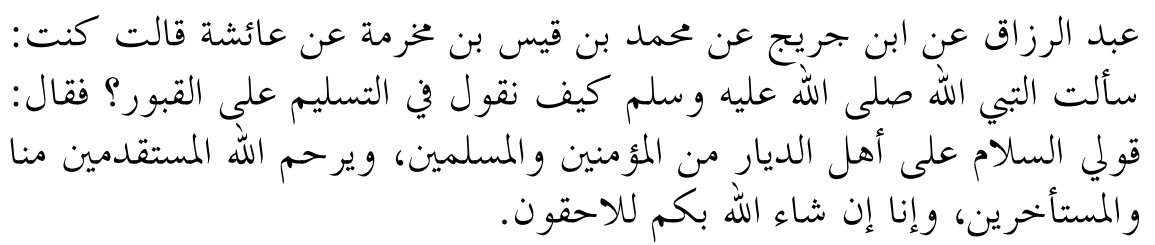

Artinya:

Dari Abdur Razzaq, dari Ibnu Juraij, dari Muhammad bin Qais bin Makhzumah, dari 'Aisyah, beliau berkata: "Aku bertanya kepada Nabi: Apa yang kami ucapkan ketika mendatangi kuburan?" Nabi Menjawab: "Usapkanlah Assalamu'alaikum (semoga kesejahteraan atas kalian) wahai penghuni kubur dari kaum lelaki yang beriman dan kaum perempuan yang beriman. Semoga Allah merahmati orang-orang yang dating lebih dahulu maupun yang dating belakangan diantara kalian. Sesungguhnya kami, Insyaallah akan menyusul kalian." (HR. Muslim no. 974).

Demikian juga bertentangan dengan hadis ini:

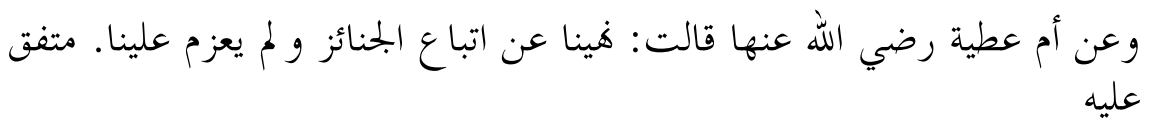


Artinya:

Dari Ummu 'Athiyah Ra., berkata: "Kami dilarang untuk mengikuti jenazah (ke pemakaman), namun beliau tidak bersungguh-sungguh (dalam melarang)." (HR. Bukhari no. 1278, Muslim no. 35/54).

Dan bertentangan juga dengan hadis di bawah ini:

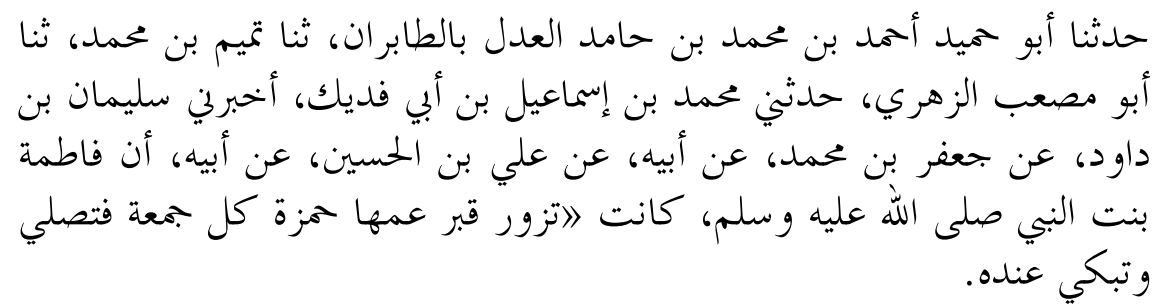

Artinya:

"Diriwayatkan dari Abu Hamid Ahmad bin Muhammad Ibnu Hamid, dari Tamim bin Muhammad, Dari Mush'ab al-Zuhri, dari Muhammad bin Ismail bin Abi Fudaik, dari Sulaiman bin Daud, dari Ja'far bin Muhammad, dari bapaknya, dari Ali bin Husein, dari bapaknya, dari Fatimah binti Muhammad, Rasulullah. Fatimah pergi menziarahi kuburan pamannya, Hamzah, setiap jum'at. Ia melakukan shalat dan menangis di samping (kuburan pamannya)." (HR. Hakim).

\section{Penyelesaian Kontradiksi Hadis}

Secara prinsip hadis shahih tidak mungkin bertentangan dengan dalil lainnya, seperti Alquran, sesama hadis dan akal. Namun dalam praktik mencari makna dalam suatu hadis sering dijumpai antara dalil satu dengan dalil lainnya, antara hadis ini dan hadis itu terkesan kontradiksi satu sama lainnya. Sehingga ulama memberikan jalan keluar dalam menyelesaikan persoalan semacam ini. 
Ketika dijumpai adanya kontradiksi antara hadis yang melaknat (melarang) ziarah kubur dengan hadis yang membolehkan melakukan ziarah kubur, maka yang perlu dilakukan adalah dengan tahapan sebagai berikut: Pertama, jika memungkinkan untuk dilakukan kompromi (al-jam'u) antara kedua hadis yang saling bertentangan, maka harus dilakukan kompromi dan wajib mengamalkan (mengambil) kedua hadis yang terkesan saling bertentangan. Kedua, hadis yang tidak dapat dikompromikan karena alasan lain maka dalam hal ini bila kita mengetahui salah satunya adalah sebagai hadis yang nasikh (menghapus hukum sebelumnya), maka hadis ini dikedepankan dan diamalkan serta meninggalkan yang mansukh (sudah dihapus hukumnya). Jika tidak diketahui antara yang menghapus (nasikh) dan yang dihapus (mansukh), maka mengamalkan hadis yang rajah (unggul) setelah mentarjihnya dengan melihat sifat-sifat rawinya dan keunggulan mereka dalam lima puluh bidang tarjih (kualifikasi). Jika tidak memungkinkan dilakukan pentarjihan antara satu dengan yang lainnya, dan ini jarang, maka kita mendiamkan (tidak mengamalkan) keduanya hingga menjadi jelas mana yang unggul dari keduanya. ${ }^{17}$

\section{Analisis Hadis Ziarah Kubur Dalam Melahirkan Hukum}

Dari perbedaan redaksi hadis di atas, yang terkesan bertentangan satu sama lainnya, maka sulit dihindari perbedaan pendapat seputar hukum perempuan mendatangi kuburuan. Adapun kemungkinan-kemungkinan munculnya perbedaan pendapat tersebut sebagaimana berikut:

- Haram dengan berpegang pada redaksi hadis yang diriwayatkan oleh Abu Hurairah yang melaknat para

17 Mahmud al-Thahhan, Taisir Musthalah al-Hadits, (Surabaya: Syirkah Bankul Indah, t.th.), 57-58. 
perempuan berziarah kubur (la'ana Rasulullah zaairaat al-qubur).

- Ditafsil (diperinci): Haram apabila perempuan tersebut sering mendatangi kuburan dengan berpegang pada redaksi hadis la'ana Allah/rasulullah zuwwaraat alqubur (para wanita yang sering ziarah kubur). Artinya, laknat (larangan) dalam hadis tersebut berlaku hanya kepada wanita yang sering mendatangi kuburan. Boleh, apabila tidak sering menziarahi kuburan [mafhum mukhalafah]. Atau sekurang-kurangnya Makruh dengan argumentasi bahwa perempuan itu kurang sabar dan sering bersedih [melihat illat].

- Boleh, dengan argumentasi bahwa hadis pelaknatan tersebut berlaku sebelum adanya dispensasi dari Rasulullah untuk ziarah kubur, sebagaimana redaksi hadis riwayat Abu Baridah, Sayyidah Aisyah dan Anas bin Malik, Ummu 'Athiyah dan Sayyidah Fatimah.

\section{Pendapat Ulama Seputar Hukum Ziarah Kubur Bagi Perempuan}

Di bawah ini akan dijelaskan perbedaan pendapat seputar hukum ziarah kubur bagi perempuan menurut pandangan empat mazhab:

1. Mayoritas Ulama (Jumhur) berpendapat bahwa ziarah kubur bagi perempuan hukumnya makruh dengan

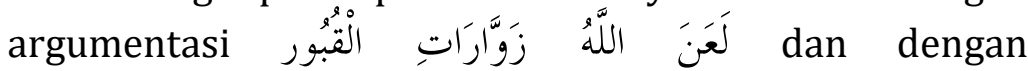
pertimbangan bahwa perempuan memiliki kelembutan hati (sehingga mudah menangis), mudah bersedih hati, kurang mampu menahan beban musibah, yang hal ini bisa membuatnya menangis dan meninggikan suaranya (menjerit). 
2. Mazhab Hanafi berpendapat dalam qaul ashah-nya (pendapat yang paling shahih), bahwa hukum perempuan melakukan ziarah kubur adalah sunnah sebagaimana laki-laki, dengan argumentasi:

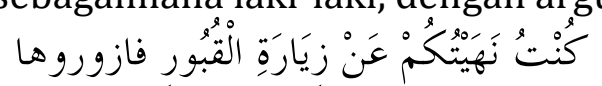

3. Mazab Maliki berpandangan bahwa hukum ziarah kubur bagi perempuan adalah makruh sebagaimana argumentasi jumhur ulama. Hanya saja Ibnu 'Abidin menganggap baik ziarah kubur bagi perempuan (tawfiqun hasanun).

4. Mazhab Syafi'i berpendapat bahwa ziarah kubur bagi perempuan hukumnya adalah makruh sebagaimana argumentasi jumhur ulama. Hanya saja Imam Ramli memberikan perincian:

- Tidak boleh apabila setiapkali ziarah kubur menyebabkan bersedih dan membuatnya menangis kembali. Disinilah berlaku hadis:

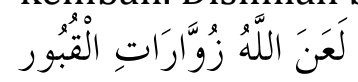

- Boleh apabila tujuan ziarah kubur untuk mengambil pelajaran dan sebagai bentuk kasih sayang dan tabarruk dengan menziarahi kuburan orang-orang shaleh, tanpa harus menangis. Kebolehan ini berlaku bagi perempuan yang sudah tua. Adapun bagi perempuan yang masih muda, maka hukumnya makruh, seperti halnya menghadiri masjid untuk shalat berjemaah.

5. Menurut kalangan Hanbali, ziarah kubur bagi perempuan hukumnya ditafsil:

- Makruh, dengan argumentasi hadis nabi

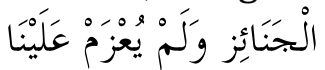

- Haram, apábila diyakini akan menimpa pada diri perempuan sesuatu yang diharamkan, karena dianggap 
termasuk kedalam kategori hadis nabi الَعَنَ اللَّهُ زُوَّارَاتِ النبّور

- Dianggap Baik, apabila seorang perempuan berjalan melewati kuburan kemudian ia membacakan salam dan berdoa.

- Sunnah, perempuan menziarahi kuburan Rasulullah dan para nabi yang lain, dengan melihat keumuman dalil anjuran ziarah kubur: فازوروها

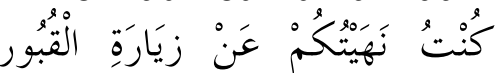

\section{Penutup}

Dari uraian di atas dapat disimpulkan bahwa adanya perbedaan redaksi hadis akan melahirkan perbedaan pendapat seputar ziarah kubur bagi seorang perempuan. Maka untuk menghasilkan rumusan hukum yang akurat dan akomodatif, sebisa mungkin dilakukan kompromisasi antara satu hadis dengan hadis lainnya. Dari penelusuran penulis seputar hadis yang berkaitan dengan hukum ziarah kubur bagi perempuan tidaklah tunggal sehingga meniscayakan melahirkan hukum yang berbeda-beda pula.

Redaksi hadis yang melaknat perempuan ziarah kubur tidak bisa serta merta distempelkan kepada seluruh perempuan yang ziarah kubur. Hal ini karena ada banyak hadis yang mengisyaratkan perempuan dibolehkan menziarahi kuburan. Belum lagi jika hadis pelaknatan kepada perempuan yang melakukan ziarah kubur dianggap sudah di nasakh oleh hadis lainnya yang menganjurkan, tentu secara otomatis hadis ini tidak berlaku lagi, kecuali illat yang menyebabkan terlaknatnya perempuan terpenuhi.

18 Al-Mausu'ah al-Fiqhiyah al-Kuwaitiyah, Cet. 2 (Kuwait: Wazarah alAwqaf wa al-syu'un al-Islamiyah, 1983), 88.

TAHDIS Volume 10 Nomor 2 Tahun 2019 
Oleh karena itu, penting untuk saling menghargai antara yang suka melakukan ziarah kubur dengan yang anti ziarah kubur. Bahwa perbedaan mazhab tidak boleh menjadi penyebab renggangnya jalinan ukhuwah antar sesama umat Islam. Bahwa yang anti ziarah kubur tak perlu menyesatkan yang suka ziarah kubur, dan yang suka melakukan ziarah kubur hendaknya menjaga norma-norma agama agar tidak terjerumus kepada kesyirikan. Wallahu a'lam bish-shawab. 


\section{DAFTAR PUSTAKA}

Abdur Rauf al-Manawi, Faidhu al-Qadir Syarah al-Jami' alShaghir, Qahirah: Dar al-Hadits, 2010.

Abu Daud Sulaiman bin al-Asy'ats al-Sajastani, Sunan Abi Daud, Beirut: Dar al-Fikr, 2011.

Abu Husein Muslim bin al-Hajjaj, Shahih Muslim, Juz 1, Beirut: Dar al-Fikr, 2011.

Al-Mausu'ah al-Fiqhiyah al-Kuwaitiyah, Cet. 2, Kuwait: Wuzarah al-Awqaf wa al-Syu'un al-Islamiyah, 1983.

Bakar bin Abdullah Abu Zaid, Juz'un fi Ziarah al-Qubur, www.du3at.com.

Ibnu Hajar al-'Asqalani, Fathu al-Bari Syarah Shahih al-Bukhari, Juz 3, al-Azhar: Dar al-Bayan al-'Arabi, 2007.

Ibnu Hajar al-'Asqalani, Tahdzib al-Tahdzib fi Rijal al-Hadits, Beirut: Dar al-Kutub al-Ilmiyah, 2004.

Ibnu Hajar al-'Asqalani, Bulughul Maram, Indonesia: Dar Ihya' al-Kutub al-Arabiyah.

Hasan bin Ali al-Qanuji al-Bukhari al-Hindi, Fath al-'Allam li Syarh Bulugh al-Maram, Juz 1, Beirut: Dar al-Kotob alIlmiyah, 1997.

Hasan Sulaiman an-Nawawi dan Alawi Abbas al-Maliki, Ibanah al-Ahkam Syarah Bulugh al-Maram, Beirut: Dar al-Fikr, 2012.

Muhammad 'Isa bin Saurah al-Tirmidzi, Sunan al-Tirmidzi, dikomentari oleh al-Bani, Riyadl: Maktabah al-Ma'arif li an-Nasyr wa al-Tawzi'.

Mahmud bin Ahmad al-Aini, 'Umdah al-Qari Syarah Shahih alBukhari, Juz 8, Beirut: Dar al-Kutub al-Ilmiyah, 2001.

Mahmud al-Thahhan, Taisir Musthalah al-Hadits, Surabaya: Syirkah Bankul Indah, t.th. 
Suyuthi, an-Nasai bi al-Musamma bi al-Mujtaba, Beirut: Dar alFikr, 1999. 